\title{
UPAYA MENINGKATKAN KOMPETENSI GURU UNTUK MENGHADAPI KEGIATAN BELAJAR DARI RUMAH DENGAN APLIKASI DISCORD PADA SMP NEGERI SATU ATAP 2 BUNGATAN TAHUN PELAJARAN 2020/2021
}

\author{
MOCH. ERFANI ${ }^{1}$ \\ ${ }^{1}$ SMP Negeri Satu Atap 2 Bungatan \\ Correspondence email: r_fani.331@gmail.com
}

Received: Marc 3, 2020 Revised: March 8, 2020 Accepted: March 11, 2020

\begin{abstract}
ABSTRAK
Guru dituntut mampu merancang dan mendesain pembelajaran daring yang ringan dan efektif, dengan memanfaatkan perangkat atau media daring yang tepat dan sesuai dengan materi yang diajarkan. Walaupun dengan pembelajaran daring akan memberikan kesempatan lebih luas dalam mengeksplorasi materi yang akan diajarkan, namun guru harus mampu memilih dan membatasi sejauh mana cakupan materinya dan aplikasi yang cocok pada materi dan metode belajar yang digunakan. Desain penelitian dalam penelitian ini adalah PTS dengan berkolaborasi dengan guru yang ditetapkan 2 siklus. Dalam PTS ada 4 tahapan yaitu perencanaan, pelaksanaan, pengamatan dan refleksi. Data primer dengan menggunakan tes ulangan dan observasi dengan di checklist, dan data sekunder dengan wawancara. Peneliti menggunakan keharusan nilai sasaran atau KKM (Kriteria Ketuntasan Minimal) menentukan kriteria sukses untuk menganalisis data.

Berdasarkan hasil penelitian pada bab IV dapat disimpulkan sebagai berikut Penerapan aplikasi discord pada SMP Negeri Satu Atap 2 Bungatan Tahun Pelajaran 2020/2021 sangat efektif. Discord merupakan salah satu aplikasi media sosial yang digunakan para gamers untuk berinteraksi, namun jika diarahkan untuk digunakan dalam pembelajaran ternyata dapat cukup bermanfaat. Melalui penelitian ini dapat diangkat kesimpulan bahwa discord dapat digunakan sebagai sarana pembelajaran secara optimal dengan syarat yaitu jaringan internet dari pendidik dan peserta didik stabil dan mencukupi. Aplikasi discord ini sangat cocok digunakan untuk presentasi layar seperti yang dapat dilakukan oleh beberapa aplikasi video conferences lainnya seperti google meet dan zoom cloud meeting.
\end{abstract}

Kata Kunci: Kompetensi Guru, Kegiatan Belajar dari Rumah, Aplikasi Discord 


\section{PENDAHULUAN}

Penyebaran pandemi virus corona atau COVID-19 telah memberikan tantangan tersendiri bagi lembaga pendidikan di Indonesia. Untuk mengantisipasi penularan virus tersebut pemerintah mengeluarkan kebijakan seperti social distancing, physical distancing, hingga pembatasan sosial berskala besar (PSBB). Kondisi ini mengharuskan masyarakat untuk tetap diam di rumah, belajar, bekerja, dan beribadah di rumah. Akibat dari kebijakan tersebut membuat sektor pendidikan seperti sekolah menghentikan proses pembelajaran secara tatap muka. Sebagai gantinya, proses pembelajaran dilaksanakan secara daring yang bisa dilaksanakan dari rumah masing-masing siswa. Sesuai dengan Surat Edaran Mendikbud Nomor 4 tahun 2020 tentang pelaksanaan kebijakan pendidikan dalam masa darurat penyebaran corona virus disease (COVID-19) menganjurkan untuk melaksanakan proses belajar dari rumah melalui pembelajaran daring. Kesiapan dari pihak penyedia layanan maupun siswa merupakan tuntutan dari pelaksanaan pembelajaran daring. Pelaksanaan pembelajaran daring ini memerlukan perangkat pendukung seperti komputer atau laptop, dan alat bantu lain sebagai perantara yang tentu saja harus terhubung dengan koneksi internet. Sistem pembelajaran daring (dalam jaringan) merupakan sistem pembelajaran tanpa tatap muka secara langsung antara guru dan siswa tetapi dilakukan melalui online yang menggunakan jaringan internet. (Ruskan,etc 454:2012).

Basori (2017:42) menyatakan bahwa Pembelajaran Daring adalah pembelajaran yang menggunakan peratalatan elektronik jaringan (LAN, WAN, atau internet) untuk menyampaikan materi pembelajaran, interaksi, maupun bimbingan. Guru harus memastikan kegiatan belajar mengajar tetap berjalan, meskipun siswa berada di rumah. Solusinya, guru dituntut dapat mendesain media pembelajaran sebagai inovasi dengan memanfaatkan media daring (online). Hal ini sesuai dengan Menteri Pendidikan dan Kebudayaan Republik Indonesia terkait Surat Edaran Nomor 4 Tahun 2020 tentang Pelaksanaan Kebijakan Pendidikan dalam Masa Darurat Penyebaran Corona Virus Disease (COVID-19). Guru merupakan unsur dominan dalam proses pendidikan, sehingga kualitas pendidikan banyak ditentukan oleh kualitas pendidik dalam menjalankan peran dan tugasnya di masyarakat (Mustofa 2007:15). Kusnandar (2008:34) menyatakan kompetensi guru adalah seperangkat penguasaan kemampuan yang harus ada dalam diri guru agar dapat mewujudkan kinerjanya secara tepat dan efektif. Sistem pembelajaran dilaksanakan melalui perangkat personal computer (PC) atau laptop yang terhubung dengan koneksi jaringan internet. Guru dapat melakukan pembelajaran bersama diwaktu yang sama menggunakan grup di media sosial seperti WhatsApp, Google Kelas, aplikasi zoom ataupun media lainnya sebagai media pembelajaran. Dengan demikian, guru dapat memastikan siswa mengikuti pembelajaran dalam waktu yang bersamaan, 
meskipun di tempat yang berbeda. Dilihat dari kejadian sekitar yang sedang terjadi, baik siswa maupun orangtua siswa yang tidak memiliki handphone untuk menunjang kegiatan pembelajaran daring ini merasa kebingungan, sehingga pihak sekolah ikut mencari solusi untuk mengantisipasi hal tersebut.

Beberapa siswa yang tidak memiliki handphone melakukan pembelajaran secara berkelompok, sehingga mereka melakukan aktivitas pembelajaran pun bersama. Permasalahan yang terjadi bukan hanya terdapat pada sistem media pembelajaran akan tetapi ketersediaan kuota yang membutuhkan biaya cukup tinggi harganya bagi siswa dan guru guna memfasilitasi kebutuhan pembelajaran daring. Kuota yang dibeli untuk kebutuhan internet menjadi melonjak dan banyak diantara orangtua siswa yang tidak siap untuk menambah anggaran dalam menyediakan jaringan internet. Pembelajaran daring tidak bisa lepas dari jaringan internet. Koneksi jaringan internet menjadi salah satu kendala yang dihadapi guru dan siswa yang tempat tinggalnya sulit untuk mengakses internet, apalagi siswa tersebut tempat tinggalnya di daerah pedesaan, terpencil dan tertinggal (Hartanto, 2016:14). Kalaupun ada yang menggunakan jaringan seluler terkadang jaringan yang tidak stabil, karena letak geografis yang masih jauh dari jangkauan sinyal seluler. Hal ini juga menjadi permasalahan yang banyak terjadi pada siswa yang mengikuti pembelajaran daring sehingga kurang optimal pelaksanaannya. Pembelajaran Daring menurut Santi (2018:54) bertujuan memberikan layanan pembelajaran bermutu secara dalam jaringan (daring) yang bersifat masif dan terbuka untuk menjangkau audiens yang lebih banyak dan lebih luas.

Beberapa guru di SMP Negeri Satu Atap 2 Bungatan mengaku, jika pembelajaran daring ini tidak begitu efektif daripada kegiatan pembelajaran konvensional (tatap muka langsung), karena beberapa materi pembelajaran harus dijelaskan secara langsung dan lebih lengkap. Selain itu materi yang disampaikan secara daring belum tentu bisa dipahami semua siswa. Berdasarkan pengalaman mengajar secara daring, sistem ini hanya efektif untuk memberi penugasan, dan kemungkinan hasil pengerjaan tugas-tugas ini diberikan ketika siswa akan masuk, sehingga kemungkinan akan menumpuk. Mengamati pengalaman dari beberapa guru tersebut, maka guru-guru di SMP Negeri Satu Atap 2 Bungatan juga harus siap menggunakan teknologi sesuai dengan perkembangan zaman. Guru harus mampu membuat model dan strategi pembelajaran yang sesuai dengan karakter siswa di sekolahnya.

Penggunaan beberapa aplikasi pada pembelajaran daring sangat membantu guru dalam proses pembelajaran ini (Hamid, 2015:32). Guru harus terbiasa mengajar dengan memanfaatkan media daring kompleks yang harus dikemas dengan efektif, mudah diakses, dan dipahami oleh siswa. Guru dituntut mampu merancang dan mendesain pembelajaran daring yang ringan dan efektif, dengan memanfaatkan perangkat atau media daring yang tepat dan sesuai dengan materi 
yang diajarkan. Walaupun dengan pembelajaran daring akan memberikan kesempatan lebih luas dalam mengeksplorasi materi yang akan diajarkan, namun guru harus mampu memilih dan membatasi sejauh mana cakupan materinya dan aplikasi yang cocok pada materi dan metode belajar yang digunakan. Hal yang paling sederhana dapat dilakukan oleh guru bisa dengan memanfaatkan WhatsApp ataupun Aplikasi Google Kelas yang dapat digunakan bagi pelajar daring pemula, karena pengoperasiannya sangat simpel dan mudah diakses siswa. Sedangkan bagi pengajar online yang mempunyai semangat yang lebih, bisa menngkatkan kemampuannya dengan menggunakan berbagai aplikasi pembelajaran daring (Afrianti, 2018:23). Dengan demikian, pembelajaran daring sebagai solusi yang efektif dalam pembelajaran di rumah guna memutus mata rantai penyebaran Covid-19, physical distancing (menjaga jarak aman) juga menjadi pertimbangan dipilihnya pembelajaran tersebut. Kerjasama yang baik antara guru, siswa, orangtua siswa dan pihak sekolah menjadi faktor penentu agar pembelajaran daring lebih efektif. Untuk itu peneliti tertarik melakukan penelitian tentang pemahaman Guru dalam pembelajaran Daring. Discord merupakan aplikasi yang seringkali digunakan oleh para gamers untuk berkomunikasi (Raihan, 2018). Discord dapat digunakan dalam sistem berbasis windows, iOS, Android, Linux, bahkan Mac. Aplikasi discord memiliki berbagai fasilitas untuk berkomunikasi yang tidak dimiliki oleh aplikasi lain. Salah satunya fitur untuk berkomunikasi layaknya telepon. Fitur ini memungkinkan pendidik untuk menyampaikan materi secara leluasa kepada peserta didik.

Berdasarkan paparan tersebut diatas maka peneliti ingin mencoba melakukan penelitian tindakan sekolah dengan tema "Upaya Meningkatkan Kompetensi Guru untuk Menghadapi Kegiatan Belajar dari Rumah dengan Aplikasi Discord pada SMP Negeri Satu Atap 2 Bungatan Tahun Pelajaran 2020/2021".

\section{Rumusan Masalah}

Berdasarkan pada latar belakang tersebut, maka dapat dirumuskan permasalahan yang ada yaitu:

1. Bagaimanakah penerapan aplikasi discord pada SMP Negeri Satu Atap 2 Bungatan Tahun Pelajaran 2020/2021?

2. Apakah upaya meningkatkan kompetensi guru untuk menghadapi kegiatan belajar dari rumah dengan aplikasi discord pada SMP Negeri Satu Atap 2 Bungatan Tahun Pelajaran 2020/2021?

\section{METODE PENELITIAN}

Metode penelitian yang digunakan pada penelitian ini adalah metode Penelitian Tindakan Sekolah (PTS) dengan model Kemmis dan Mc. Taggart yang merupakan model pengembangan dari model Kurt Lewin. Dikatakan demikian, karena di dalam suatu siklus terdiri atas empat komponen, 
keempat komponen tersebut, meliputi: (1) perencanaan, (2) aksi/ tindakan, (3) observasi, dan (4) refleksi. Setelah suatu siklus selesai diimplementasikan, khususnya sesudah adanya refleksi, kemudian diikuti dengan adanya perencanaan ulang yang dilaksanakan dalam bentuk siklus tersendiri.

Menurut Kemmis dan Mc. Taggart, penelitian tindakan dapat dipandang sebagai suatu siklus spiral dari penyusunan perencanaan, pelaksanaan tindakan, pengamatan (observasi), dan refleksi yang selanjutnya mungkin diikuti dengan siklus spiral berikutnya. Dalam pelaksanaannya, ada kemungkinan peneliti telah mempunyai seperangkat rencana tindakan (yang didasarkan pada pengalaman) sehingga dapat langsung memulai tahap tindakan. Ada juga peneliti yang telah memiliki seperangkat data, sehingga mereka memulai kegiatan pertamanya dengan kegiatan refleksi.

\section{Penyusunan Perencanaan}

Penyusunan perencanaan didasarkan pada hasil penjajagan refleksi awal. Secara rinci perencanaan mencakup tindakan yang akan dilakukan untuk memperbaiki, meningkatkan atau mengubah perilaku dan sikap yang diinginkan sebagai solusi dari masalah penelitian. Perlu disadari bahwa perencanaan ini bersifat fleksibel dalam arti dapat berubah sesuai dengan kondisi nyata yang ada.

\section{Pelaksanaan Tindakan}

Pelaksanaan tindakan menyangkut apa yang dilakukan peneliti sebagai upaya perbaikan, peningkatan atau perubahan yang dilaksanakan berpedoman pada rencana tindakan. Jenis tindakan yang dilakukan dalam PTS hendaknya selalu didasarkan pada pertimbangan teoretik dan empirik agar hasil yang diperoleh berupa peningkatan kinerja dan hasil program yang optimal.

3. Observasi (pengamatan)

Kegiatan observasi dalam PTS dapat disejajarkan dengan kegiatan pengumpulan data dalam penelitian formal. Dalam kegiatan ini, peneliti mengamati hasil atau dampak dari tindakan yang dilaksanakan atau dikenakan terhadap siswa. Istilah observasi digunakan karena data yang dikumpulkan melalui teknik observasi.

4. Refleksi

Pada dasarnya kegiatan refleksi merupakan kegiatan analisis, sintesis, interpretasi terhadap semua informasi yang diperoleh saat kegiatan tindakan. Dalam kegiatan ini, peneliti mengkaji, melihat, dan mempertimbangkan hasil-hasil atau dampak dari tindakan. Setiap informasi yang terkumpul perlu dipelajari kaitan yang satu dengan lainnya dan kaitannya dengan 
teori atau hasil penelitian yang telah ada dan relevan. Melalui refleksi yang mendalam dapat ditarik kesimpulan yang mantap dan tajam.

Refleksi merupakan bagian yang sangat penting dari PTS yaitu untuk memahami proses dan hasil yang terjadi, yaitu berupa perubahan sebagai akibat dari tindakan yang dilakukan. Pada hakikatnya, model Kemmis dan Taggart berupa perangkat-perangkat atau untaian dengan setiap perangkat terdiri dari empat komponen yaitu perencanaan, tindakan, pengamatan, dan refleksi yang dipandang sebagai suatu siklus.

Teknik pengolahan dan analisis data dilakukan secara kuantitatif dan kualitatif. Teknik pengolahan data secara kuantitatif dilakukan terhadap variabel kualitas pembelajaran. Data yang diperoleh dari hasil pengamatan atau observasi kualitas pembelajaran dalam mengembangkan materi pembelajaran yang terdiri dari enam aspek perilaku pembelajaran guru, perilaku dan dampak belajar siswa, iklim pembelajaran, materi pembelajaran, media pembelajaran, dan sistem pembelajaran diolah dengan menentukan nilai rata-ratanya. Analisis data kualitas pembelajaran dilakukan menggunakan prosentase (\%), yakni perhitungan yang digunakan untuk mengetahui tingkat prosentase skor penilaian dari masing-masing indikator kualitas pembelajaran dalam mengembangkan materi pembelajaran. Rumus yang digunakan adalah sebagai berikut:

Prosentase $(\%)=\frac{\sum n}{N} \times 100 \%$

Dimana:

$\sum \mathrm{n}=$ Jumlah skor jawaban responden

$\mathrm{N}=$ Jumlah skor jawaban ideal

$\%=$ Tingkat persentase

(Mohammad Ali, 2007:184)

Data kuantitatif berupa prosentase tersebut kemudian dijadikan dasar untuk dikonversi kedalam data kualitatif menggunakan kriteria berikut.

\section{Kriteria Kompetensi dan Kompetensi Guru}

\begin{tabular}{|c|c|}
\hline Skor & Kriteria \\
\hline $91-100$ & Sangat Baik \\
\hline $76-90$ & Baik \\
\hline $61-75$ & Cukup \\
\hline $51-60$ & Kurang \\
\hline$\leq 50$ & Sangat Kurang \\
\hline
\end{tabular}

Teknik pengolahan data kualitatif dilakukan terhadap variabel proses pembinaan Guru yang dikumpulkan melalui lembar observasi proses pembinaan Guru yang diolah dengan cara 
mengkategorikan dan mengklasifikasikan data berdasarkan analisis kaitan logis, kemudian ditafsirkan dalam konteks permasalahan penelitian. Kegiatan ini berupaya memunculkan makna dari setiap data yang didapat, sehingga data itu tidak hanya bersifat deskriptif. Dalam penelitian dengan pendekatan kualitatif, pengolahan dan analisis data dilakukan secara terus-menerus dari awal sampai akhir pelaksanaan program tindakan.

\section{A. Prosedur Penelitian}

Prosedur penelitian tindakan sekolah pada penelitian ini mengikuti model Kemmis dan Mc. Taggart yang terdiri dari perencanaan, pelaksanaan, observasi dan refleksi tindakan yang telah diterapkan yaitu penerapan aplikasi discord untuk meningkatkan kualitas pembelajaran. PTS yang telah dilakukan ini terdiri dari dua siklus yang masing-masing terdiri dari satu kali pembinaan Guru untuk masing-masing guru. Berikut prosedur penelitian yang telah dilaksanakan:

\section{Perencanaan tiap Siklus}

a. Perencanaan

1) Sosialisasi penggunaan aplikasi discord dan instalasi aplikasi discord pada guru

2) Pelatihan dan diskusi aplikasi discord antar rekan guru

3) Pengimbasan pada peserta didik

4) Merencanakan proses pembinaan Guru sesuai dengan prinsip-prinsip aplikasi discord .

5) Menyusun instrumen penelitian berupa lembar observasi proses pembinaan Guru, lember observasi kualitas pembelajaran guru dalam mengembangkan materi pembelajaran, panduan wawancara dan catatan lapangan.

6) Melakukan analisis penerapan aplikasi discord guru pada peserta didik.

7) Sesuai jadwal, peneliti memberikan materi tentang teknis pendalaman aplikasi discord.

8) Menyepakati jadwal kegiatan pada pertemuan berikutnya.

b. Pelaksanaan Tindakan

Dalam penelitian ini yang bertindak sebagai pengajar adalah guru-guru. Pada tahap ini dilakukan suatu tindakan untuk menghasilkan adanya peningkatan dalam proses pembelajaran yang berupa pembelajaran menjadi lebih efektif, siswa menjadi lebih aktif dan hasil belajar meningkat. Hal-hal yang dilakukan pada tahap pelaksanaan tindakan adalah implementasi aplikasi discord yang telah disusun oleh peneliti.

Penelitian di pertemuan kedua dan ketiga saat guru di semester pertama. Pertemuan pertama dari penelitian menjadi proses adaptasi guru terhadap platform baru yang tidak pernah mereka gunakan sebelumnya dalam pembelajaran. Platform yang digunakan adalah platform aplikasi discord yang bisa digunakan baik di android maupun di desktop. 
Pertemuan kedua penelitian yang merupakan pertemuan ketiga dalam pembelajaran. Dalam pertemuan ini data mulai diambil menjelang pembelajaran selesai menggunakan metode survei menggunakan google forms secara daring. Masing-masing peserta dimintai tanggapannya terhadap pembelajaran yang telah dilangsungkan melalui platform discord.

c. Observasi

Sesuai dengan jadwal dan rencana kegiatan yang telah ditentukan dalam perencanaan siklus I. Mengumpulkan data tentang komitmen guru dalam melaksanakan kegiatan pembelajaran dengan aplikasi discord, dan melakukan penilaian kemampuan guru dalam pengaplikasian aplikasi discord

d. Tahap Analisis dan Refleksi

mengumpulkan data tentang komitmen guru dalam melaksanakan kegiatan, - melakukan penilaian kemampuan guru dalam menggunakan aplikasi discord dalam pembelajaran

\section{HASIL PENELITIAN DAN PEMBAHASAN}

\section{A. Hasil Penelitian}

1. Siklus I

Proses pelaksanaan siklus I melalui empat tahapan, yakni: a) perencanaan, b) pelaksanaan, c) observasi, dan d) refleksi. Penjelasannya masing-masing tahapan adalah sebagai berikut:

a. Perencanaan

1) Menyerahkan lembar/instrumen penilaian kompetensi guru kepada kolaborator. Instrumen ini diadopsi dari Lampiran Penilaian Kompetensi Guru. Discord yang digunakan sebagai alternatif dari pertemuan tatap muka yang diganti dengan video dan audio conferencing yang dapat diakses oleh siswa dan guru untuk tetap menjaga kualitas sehingga proses pembelajaran tetap berjalan meskipun di tengah wabah yang melanda negeri ini. Beragam aplikasi atau media pembelajaran bertebaran di tengah pandemi covid-19, namun peneliti lebih tertarik dengan menggunakan Discord karena lebih terjaga keamanannya dan efektif dalam melakukan diskusi atau pembahasan materi dengan komunikasi yang didukung dengan fitur-fitur yang terdapat di Discord seperti pesan grup sehingga jika ada kendala secara audio dapat dibantu dengan fiturchat yang tersedia.

2) Peneliti/Kolaborator mengamati pelaksanaan tindakan didalam kelas dengan mengisi instrumen penilaian kineja guru sesuai dengan hasil pengamatan

b. Pelaksanaan 
Pelaksanaan kegiatan belajar mengajar untuk siklus I dilaksanakan oleh guru-guru. Dalam hal ini peneliti bertindak sebagai guru. Adapun proses belajar mengajar mengacu pada rencana pelajaran yang telah dipersiapkan. Pengamatan (observasi) dilaksanakan bersamaan dengan pelaksaaan belajar mengajar. Pada akhir proses belajar mengajar siswa diberi tes formatif I dengan tujuan untuk mengetahui tingkat keberhasilan siswa dalam proses belajar mengajar yang telah dilakukan.

Pengamatan (observasi) dilaksanakan bersamaan dengan pelaksaaan belajar mengajar. Pada akhir proses belajar mengajar siswa diberi tes formatif I dengan tujuan untuk mengetahui tingkat keberhasilan siswa dalam proses belajar mengajar yang telah dilakukan. Adapun data hasil penelitian pada siklus I adalah sebagai berikut:

1) Penelitian di pertemuan kedua dan ketiga saat guru di semester pertama. Pertemuan pertama dari penelitian menjadi proses adaptasi guru terhadap platform baru yang tidak pernah mereka gunakan sebelumnya dalam pembelajaran. Platform yang digunakan adalah platform discord yang bisa digunakan baik di android maupun di desktop.

2) Pertemuan kedua penelitian yang merupakan pertemuan ketiga dalam pembelajaran. Dalam pertemuan ini data mulai diambil menjelang pembelajaran selesai menggunakan metode survei menggunakan google forms secara daring. Masing-masing peserta dimintai tanggapannya terhadap pembelajaran yang telah dilangsungkan melalui platform discord

\section{c. Observasi}

Pada tahapan observasi ini penulis melakukan monitoring pelaksanaan penerapan aplikasi discord yang meliputi monitoring perencanaan sampai akhir pelaksanaan penerapan aplikasi discorduntuk mengetahui perkembangan dan mengidentifikasi apakah kegiatan penerapan aplikasi discorddijalankan sesuai perencanaan atau tidak. Instrumen monitoring terlampir. Selain itu penulis juga melakukan evaluasi di akhir pelaksanaan penerapan aplikasi discorduntuk mengetahui pencapaian indikator keberhasilan melalui lembar observasi Aplikasi Discord. Observasi dilakukan oleh penulis sejak awal hingga akhir kegiatan yang dilaksanakan oleh kepala sekolah, guru, dan guru. Berdasarkan hasil observasi diperoleh beberapa catatan serta hasil penilaian terhadap kemampuan masing-masing. Berikut ini ringkasnya hasil catatan dan penilaian tersebut

Berdasarkan hasil observasi diperoleh beberapa catatan serta hasil penilaian terhadap kemampuan masing-masing. 
Berikut ini ringkasnya hasil catatan dan penilaian tersebut

\section{HASIL OBSERVASI GURU SIKLUS 1}

\begin{tabular}{|c|c|c|c|c|c|c|c|c|c|c|c|c|c|c|c|c|c|c|c|c|}
\hline \multirow{3}{*}{ No } & \multirow{3}{*}{ Nama } & \multicolumn{16}{|c|}{ Aspek Observasi } & \multirow{3}{*}{$\mathrm{Jml}$} & \multirow{3}{*}{$\%$} & \multirow{3}{*}{ Kategori } \\
\hline & & \multicolumn{4}{|c|}{$\begin{array}{c}\text { Kemampuan } \\
\text { TIK }\end{array}$} & \multicolumn{4}{|c|}{$\begin{array}{l}\text { Mendowmload } \\
\text { Aplikasi }\end{array}$} & \multicolumn{4}{|c|}{$\begin{array}{c}\text { Interaksi } \\
\text { dengan siswa }\end{array}$} & \multicolumn{4}{|c|}{ Mengadakan diskusi } & & & \\
\hline & & 1 & 2 & 3 & $\begin{array}{c}\text { Sko } \\
\text { r }\end{array}$ & 1 & 2 & 3 & Skor & 1 & 2 & 3 & skor & 1 & 2 & 3 & Skor & & & \\
\hline 1 & $\mathrm{AD}$ & & & $\sqrt{ }$ & 3 & & $\sqrt{ }$ & & 2 & & & $\sqrt{ }$ & 3 & & $\sqrt{ }$ & & 2 & 10 & 83 & Baik \\
\hline 2 & $\mathrm{AM}$ & & $\sqrt{ }$ & & 2 & & $\sqrt{ }$ & & 2 & & $\sqrt{ }$ & & 2 & & $\sqrt{ }$ & & 2 & 8 & 67 & C. Baik \\
\hline 3 & $\mathrm{BC}$ & & $\sqrt{ }$ & & 2 & & $\sqrt{ }$ & & 2 & & $\sqrt{ }$ & & 2 & $\sqrt{ }$ & & & 1 & 7 & 58 & Kurang \\
\hline 4 & CA & & & $\sqrt{ }$ & 3 & & & $\sqrt{ }$ & 3 & & & & 2 & $\sqrt{ }$ & & & 1 & 9 & 75 & C. Baik \\
\hline 5 & DI & & $\sqrt{ }$ & & 2 & $\sqrt{ }$ & & & 1 & $\sqrt{ }$ & & & 1 & & & $\sqrt{ }$ & 3 & 7 & 58 & Kurang \\
\hline 6 & $\mathrm{DH}$ & $\sqrt{ }$ & & & 1 & $\sqrt{ }$ & & & 1 & $\sqrt{ }$ & & & 1 & & $\sqrt{ }$ & & 2 & 5 & 42 & Kurang \\
\hline 7 & DR & $\sqrt{ }$ & & & 1 & & $\sqrt{ }$ & & 2 & $\sqrt{ }$ & & & 1 & & $\sqrt{ }$ & & 2 & 6 & 50 & Kurang \\
\hline 8 & WY & & $\sqrt{ }$ & & 2 & & $\sqrt{ }$ & & 2 & & & $\sqrt{ }$ & 3 & & & $\sqrt{ }$ & 3 & 10 & 83 & Baik \\
\hline \multicolumn{2}{|c|}{ Jumlah } & 2 & 4 & 2 & 16 & 2 & 5 & 1 & 15 & 3 & 2 & 2 & 15 & 2 & 4 & 2 & 16 & & & \\
\hline \multicolumn{2}{|c|}{ Skor Maksimal } & \multicolumn{3}{|c|}{24} & \multicolumn{4}{|c|}{24} & \multicolumn{4}{|c|}{24} & \multicolumn{5}{|c|}{24} & & & \\
\hline \multicolumn{2}{|c|}{$\%$ indikator } & \multicolumn{3}{|c|}{67} & \multicolumn{4}{|c|}{63} & \multicolumn{4}{|c|}{63} & \multicolumn{5}{|c|}{67} & & & \\
\hline \multicolumn{2}{|c|}{ Kategori } & \multicolumn{3}{|c|}{ Cukup Baik } & \multicolumn{4}{|c|}{ Cukup Baik } & \multicolumn{4}{|c|}{ Cukup Baik } & & \multicolumn{4}{|c|}{ Cukup Baik } & & & \\
\hline \multicolumn{2}{|c|}{$\%$ siklus 1} & \multicolumn{16}{|c|}{65} & & & \\
\hline \multicolumn{2}{|c|}{ Kategori } & \multicolumn{16}{|c|}{ Cukup Baik } & & & \\
\hline
\end{tabular}

Berdasarkan uraian tersebut bahwa dinilai mampu memenuhi tuntutan komponen ini. Untuk komponen materi pokok, dinilai kurang memenuhi tuntutan tujuan pembelajaran. Pemilihan aplikasi discord, sudah dilakukan, meski akurasinya untuk mencapai tujuan pembelajaran masih diragukan. Setelah dalam menjelaskan langkahlangkah pembelajaran dinilai kurang mampu mengaktualisasikan karakter. Demikian pula dalam penilaian pembelajaran, tidak mencantum prosedur dan pedoman penilaian yang jelas, kriteria yang tepat untuk menentukan batas minimal tuntas.

Pada akhir siklus I ini diadakan refleksi berdasarkan data / hasil pengamatan peneliti/kolaborator agar peneliti dapat melihat bahwa supervisi akademik yang dilakukan dalam penelitian ini dapat meningkatkan kompetensi guru. Kompetensi guru-guru:

1) Dari hasil wawancara dengan guru-guru, diketahui alasan mengapa guru-guru kurang antusias dan dorongan kurang kuat. Alasannya karena aplikasi discord sesuai dengan format sertifikasi guru dianggap bukan hal baru dan guru tidak merasa mendapat sesuatu yang baru.

2) Komponen komitmen yang nilainya baik pada siklus I adalah komponen waktu, yaitu hadir setiap kegiatan, hadir/pulang tepat waktu dan menyelesaikan tugas tepat waktu. 
Kemampuan guru-guru :

1. Terjadi peningkatan nilai kemampuan dengan rata-rata nilai

2. Dengan Pola Konvensional : pendekatan $\rightarrow$ strategi $\rightarrow$ metode $\rightarrow$ teknik, guru mengalami kesulitan menentukan metode untuk mendukung strategi diskoveri inkuiri. Ceramah, tanya jawab, demonstrasi, penugasan adalah metoda-metoda konvensional yang selalu digunakan guru.

3. Dari hasil wawancara diketahui penyebabnya, karena guru-guru belum paham dengan modelmodel pembelajaran Inovatif. Akibatnya guru-guru masih kesulitan mengubah strategi "ekspositori" manjadi "diskoveri inkuiri".

Lain dari pada itu, seluruh aplikasi discord belum memunculkan Tugas Terstruktur dan Kegiatan Mandiri tak terstruktur, sehingga rata-rata untuk kelengkapan aplikasi discord baru mencapai $65 \%$.

HASIL OBSERVASI GURU SIKLUS 2

\begin{tabular}{|c|c|c|c|c|c|c|c|c|c|c|c|c|c|c|c|c|c|c|c|c|}
\hline \multirow{3}{*}{ No } & \multirow{3}{*}{ Nama } & \multicolumn{16}{|c|}{ Aspek Observasi } & \multirow{3}{*}{$\begin{array}{c}\mathrm{Jm} \\
1\end{array}$} & \multirow{3}{*}{$\%$} & \multirow{3}{*}{$\begin{array}{c}\text { Katego } \\
\text { ri }\end{array}$} \\
\hline & & \multicolumn{4}{|c|}{$\begin{array}{l}\text { Kemampuan } \\
\text { TIK }\end{array}$} & \multicolumn{4}{|c|}{$\begin{array}{l}\text { Mendowmload } \\
\text { Aplikasi }\end{array}$} & \multicolumn{4}{|c|}{$\begin{array}{c}\text { Interaksi dengan } \\
\text { siswa }\end{array}$} & \multicolumn{4}{|c|}{$\begin{array}{l}\text { Mengadakan } \\
\text { diskusi }\end{array}$} & & & \\
\hline & & 1 & 2 & 3 & Skor & 1 & 2 & 3 & $\begin{array}{l}\text { Sk } \\
\text { or }\end{array}$ & 1 & 2 & 3 & skor & 1 & 2 & 3 & Skor & & & \\
\hline 1 & $\mathrm{AD}$ & $\sqrt{ }$ & & & 1 & & & $\sqrt{ }$ & 3 & & & $\sqrt{ }$ & 3 & & $\sqrt{ }$ & & 2 & 9 & 75 & C. Baik \\
\hline 2 & $\mathrm{AM}$ & & & $\sqrt{ }$ & 3 & & $\sqrt{ }$ & & 2 & & & $\sqrt{ }$ & 3 & & $\sqrt{ }$ & & 2 & 10 & 83 & Baik \\
\hline 3 & $\mathrm{BC}$ & & $\sqrt{ }$ & & 2 & & & $\sqrt{ }$ & 3 & & & $\sqrt{ }$ & 3 & & & $\sqrt{ }$ & 3 & 11 & 92 & S Baik \\
\hline 4 & $\mathrm{CA}$ & & & $\sqrt{ }$ & 3 & & & $\sqrt{ }$ & 3 & & $\sqrt{ }$ & & 2 & & & $\sqrt{ }$ & 3 & 11 & 92 & S Baik \\
\hline 5 & DI & & $\sqrt{ }$ & & 2 & & & $\sqrt{ }$ & 3 & & & $\sqrt{ }$ & 3 & & $\sqrt{ }$ & & 2 & 10 & 83 & Baik \\
\hline 6 & DH & & & $\sqrt{ }$ & 3 & & $\sqrt{ }$ & & 2 & & & $\sqrt{ }$ & 3 & & & $\sqrt{ }$ & 3 & 11 & 92 & S Baik \\
\hline 7 & DR & & & $\sqrt{ }$ & 3 & & & $\sqrt{ }$ & 3 & & $\sqrt{ }$ & & 2 & & $\sqrt{ }$ & & 2 & 10 & 83 & Baik \\
\hline 8 & WY & & & $\sqrt{ }$ & 3 & & & $\sqrt{ }$ & 3 & & & $\sqrt{ }$ & 3 & $\sqrt{ }$ & & & 1 & 10 & 83 & Baik \\
\hline & & 1 & 2 & 5 & 20 & 0 & 2 & 6 & 22 & 0 & 2 & 6 & 22 & 1 & 4 & 3 & 18 & & & \\
\hline & aksimal & & & 24 & & & & 24 & & & & 24 & & & & 24 & & & & \\
\hline & icator & & & 83 & & & & 92 & & & & 92 & & & & 75 & & & & \\
\hline & gori & & Sang & gat B & aik & & Sangc & at $\mathrm{Ba}$ & & & Sang & gat $\mathrm{B}$ & aik & & San & gat & aik & & & \\
\hline & clus 2 & & & & & & & & & 85 & & & & & & & & & & \\
\hline & gori & & & & & & & & & $\mathrm{Ba}$ & & & & & & & & & & \\
\hline
\end{tabular}

Berdasarkan tabel di atas Selama melakukan serangkaian kegiatan penerapan aplikasi discord) siklus II, guru terlihat antuasias dalam menyimak, bertanya, dan mengumpulkan materi untuk menyusun aplikasi discord. Seperti halnya pada siklus I, monitoring dilaksanakan untuk mengukur tingkat keberhasilan dari kegiatan pembuatan aplikasi discord. 
Hasil telah terhadap aplikasi discord.

a. Refleksi

Pada akhir tiap siklus diadakan refleksi berdasarkan data instrumen penilaian kompetensi guru agar peneliti dapat melihat apakah tindakan yang dilakukan dalam penelitian ini dapat meningkatkan kualitas kompetensi guru dalam proses pembelajaran di SMP Negeri Satu Atap 2 Bungatan. Refleksi dilaksanakan pada akhir siklus, dimaksudkan untuk mengetahui berbagai masalah yang muncul pada pelaksanaan tindakan siklus II. Kekurangan pada siklus I telah diperbaiki pada kegiatan penerapan aplikasi discordsiklus II. Tidak ada kendala yang berarti pada pelaksanaan siklus II ini. ebelum pelaksanaan penerapan aplikasi discordnampak bahwa Standar Proses memperoleh skor paling rendah dibanding Standar lainnya. Standar Proses tersebut merupakan tolok ukur terhadap kemampuan guru dalam merencanakan, melaksanakan dan mengevaluasi hasil pembelajaran. Hal ini dapat diartikan bahwa masih rendahnya kemampuan guru dalam menyusun aplikasi discord.

Pelaksanaan siklus I dilaksanakan setelah melihat kondisi awal, kemudian dimulai dengan memberikan bimbingan dan materi menyusun aplikasi discord/administrasi guru untuk satu hari, hasilnya dinilai peneliti dan kolaborator dengan menggunakan instrumen supervisi yang disiapkan peneliti. Kemudian kolaborator menyerahkan kepada peneliti beserta hasilnya. Hasil pada siklus I rata-rata 65 naik 35\% dibanding kondisi awal sehingga masih belum maksimal maka perlu pembekalan kepada guru-guru pada tindakan siklus II.

Setelah mengetahui kekurangan kemampuan/kompetensi guru pada siklus I peneliti memberikan pembekalan tentang kekurang sempurnaan yang telah dilaksanakan oleh guru agar lebih baik pada siklus II, terbukti hasilnya meningkat 35\% dibanding hasil siklus I

\section{KESIMPULAN}

Aplikasi discord ini tidak cocok jika harus digunakan untuk presentasi layar seperti yang dapat dilakukan oleh beberapa aplikasi video conferences lainnya seperti google meet dan zoom cloud meeting. Hal ini disebabkan karena tingginya pengaruh kestabilan jaringan internet terhadap optimalnya fungsi voice call maupun video conferences dari discord.

Ada upaya meningkatkan kompetensi guru untuk menghadapi kegiatan belajar dari rumah dengan aplikasi discord pada SMP Negeri Satu Atap 2 Bungatan Tahun Pelajaran 2020/2021 


\section{DAFTAR PUSTAKA}

Absor, N. F. (2020). Pembelajaran Sejarah Abad 21: Tantangan dan Peluang dalam Menghadapi Pandemi Covid-19. Chronologia: Journal of History Education, 2(1), 30-35. doi:http://dx.doi.org/ 10.22236/jhe.v2i1.5502

Bafadal, 2004. Manajemen Perlengkapan Sekolah Teori dan Aplikasinya. Jakarta: Bumi Aksara.

Buwono, S., \& Dewantara, J. A. (2020). Hubungan Media Internet, Membaca, dan Menulis dalam Literasi Digital Mahasiswa. Jurnal Basicedu, 4(4), 1186-1193.

Daresh, 2009, Kerangka Dasar Sistem Informasi Manajemen. Jakarta Pusat: PT Ikrar Madiri Abadi.

Dessler, 2007. Manajemen Sumber Daya Manusia: Pendekatan Non Sekuler. Surakarta: Muhammadiyah University Press.

Dewantara, J. A., Efriani, \& Afandi. (2020). Pemanfaatan aplikasi discord sebagai media pembelajaran online. Jurnal teknologi informasi dan pendidikan, 13(1), 61-65.

Eheren 2006. Pembelajaran Metode Kasus. Yogyakarta: CV Adi Offset.

Gibson, 2007. Manajemen Sumber Daya Manusia Strategik. Jakarta: Ghalia Indonesia.

Glickman, et al; 2007. Kerangka Dasar Sistem Informasi Manajemen. Jakarta Pusat: PT Ikrar Madiri Abadi

Hani Handoko, 2004. Manajemen Personalia dan Sumberdaya Manusia. BPFE, Yogyakarta

Imron, 2012. Konsep Dasar \& Teknik Supervisi Pendidikan. Jakarta: PT Rineka Cipta

Isjoni, 2004. Manajemen Pendidikan. Surakarta: Fairuz Media

Kholisho, Y. N., \& Marfuatun. (2020). Daya Serap Pelaksanaan Mata Kuliah Kependidikan DiTengah Pandemi Covid-19. Edumatic: Jurnal Pendidikan Informatika, 4(1), 131- 140.

Kusmianto, 2007. Interaksi dan Motivasi Belajar Mengajar. Jakarta: PT Raja Grafindo Persada

Lovell \& Wiles, 2008. Developing the Curriculum.(Third Edition). New York. Harper Collins Publishers Inc

Lunenbrug \& Beverly, 2006. Curriculum Alternative Approaches, OngoingIssues. USA: Pearson.

Malthis dan Jackson, 2001. Curriculum for a New Millennium. USA: Allyn \& Bacon.

Mangkupawira, 2001. Bisnis, Manajemen, dan Sumberdaya Manusia. Bogor: IPB Press,

Mantja, 2002. Panduan Manajemen Mutu Kurikulum Pendidikan. Yogyakarta: DIVA Press

Mulyasa, 2007. Standar Kompetensi dan Sertifikasi Guru. Bandung: PT. Remaja. Rosdakarya 
Oliva, 2004, Developing the Curriculum.(Third Edition). New York. Harper Collins Publishers Inc.

Purwanto, 2004. Landasan Kependidikan, Stimulus Ilmu Pendidikan Bercorak Indonesia. Jakarta: PT Rineka Cipta

Raihan, J. P., \& Putri, Y. R. (2018). Pola komunikasi group discord PUBG.INDO.FUN melalui aplikasi discord. e-Proceeding of Management, 5(3), 4161-4169.

Sahartian, 2008. Konsep Dasar \& Teknik Supervisi Pendidikan. Jakarta: PT Rineka Cipta

Sergiovanni, 2001, Developing the Curriculum.(Third Edition). New York. Harper Collins Publishers Inc.

Soedijarto, 2003. Kebijakan Pembaruan Pendidikan, Konsep, dan Model. Jakarta:Rajawali Pers

Tilaar, 2009: Asas-asas Kurikulum. Jakarta: Bumi Aksara

Wulanjani, A. N. (2018). DISCORD APPLICATION: Turning a Voice Chat Application for Gamers into a Virtual Listening Class. 2nd English Language and Literature International Conference (ELLiC) Proceedings. 2, hal. 115-119. Semarang: Unimus. 